\title{
Development of the Asian Tethyan Realm
}

\author{
Xiaochi Jin ${ }^{1}$ Wenjiao Xiao ${ }^{2,3}$
}

Published online: 3 May 2017

(C) Springer-Verlag Berlin Heidelberg 2017

More than 120 years have passed since E. Suess introduced the concept of Tethys in (1893). Successive studies made us known of the spatial extent and structural framework of the Tethysides, i.e. the products of the evolution of Tethys (e.g. Gregory 1915; Şengör et al. 1988; Şengör and Natal'in 1996; Pubellier 2008; Ren et al. 2013), meanwhile, also revealed the extreme complexity of the evolving history of Tethys (e.g. Huang and Chen 1987; Şengör et al. 1988; Jin et al. 2003, 2015; Sengör and Atayman 2009; Wopfner and Jin 2009; Metcalfe 2013).

The Tethysides are a superorogenic complex stretching from southern Europe to south and east Asia (Şengör and Natal'in 1996; Pubellier 2008; Ren et al. 2013). To the west of the Pamir syntaxis the superorogenic complex is in the form of a broad band or zone, and changes to the east of the Pamir syntaxis into roughly a large triangular territory (Fig. 1). Within the Tethysides we are better informed of the regional distribution of continental blocks (and/or terranes) of varied origins, and the extensions of suture zones that join these blocks (and/or terranes). We are, however, of limited knowledge but plentiful speculations on the mechanism and process of rifting, drifting and amalgamation.

Xiaochi Jin

jinxchi@sina.com; jinxchi@cags.ac.cn

Wenjiao Xiao

wj-xiao@mail.iggcas.ac.cn

1 Institute of Geology, Chinese Academy of Geological Sciences, 26 Baiwanzhaung Road, Beijing 100037, China

2 Division of Tethys Research Center, Institute of Geology and Geophysics, Chinese Academy of Sciences, Beijing 100029, China

3 CAS Center for Excellence in Tibetan Plateau Earth Science, Chinese Academy of Sciences, Beijing 100101, China
This deficiency hinders us from reaching a reasonable depiction of the evolution of Tethys. The diversification of various palinspastic reconstructions is a picturesque annotation of this problem. Idealized arrangement of continental blocks and motive-driven motion of them are actually a helpless result of limited available multi-disciplinary constraints on forms and sizes of oceanic basins and positions of continent blocks in different times. Continuous investigation is the only way to minimize the uncertainties and to increase confidence.

The International Geoscience Programme Project 589 (IGCP-589) entitled "Development of the Asian Tethyan Realm: Genesis, Process and Outcomes" is a successor project of several IGCP projects (321, 411 and 516) that dealt with the geological evolution of Asia with emphasis on Gondwana dispersion and Asia accretion. IGCP-589 is aimed to carry out multi-disciplinary investigations in key areas of the Tethysides to help explore the evolution of the Asian Tethyan Realm. Specific studies includes regional extension of suture zones; properties of oceanic basins and the positions of continental blocks at different times; stratigraphic successions on continental blocks; paleobiogeographic evolution; timing and processes of continental blocks rifting and suturing; and testing the validity of the existing Tethyan evolution models. Geologists from around 20 countries take part in the project.

IGCP-589 started in 2012. In that year the first international symposium of the project was held in Xi' an, China with a post-symposium excursion to the Qinling Orogen. We also held in August jointly with the CGMW project "International Geological Map of Asia" the symposium "Geological Processes of the construction of Asia" at the 34th IGC in Brisbane, Australia. Papers presented at these two symposia formed the core of the first special issue of IGCP-589 (Journal of Asian Earth Sciences, 104 (2015)). 


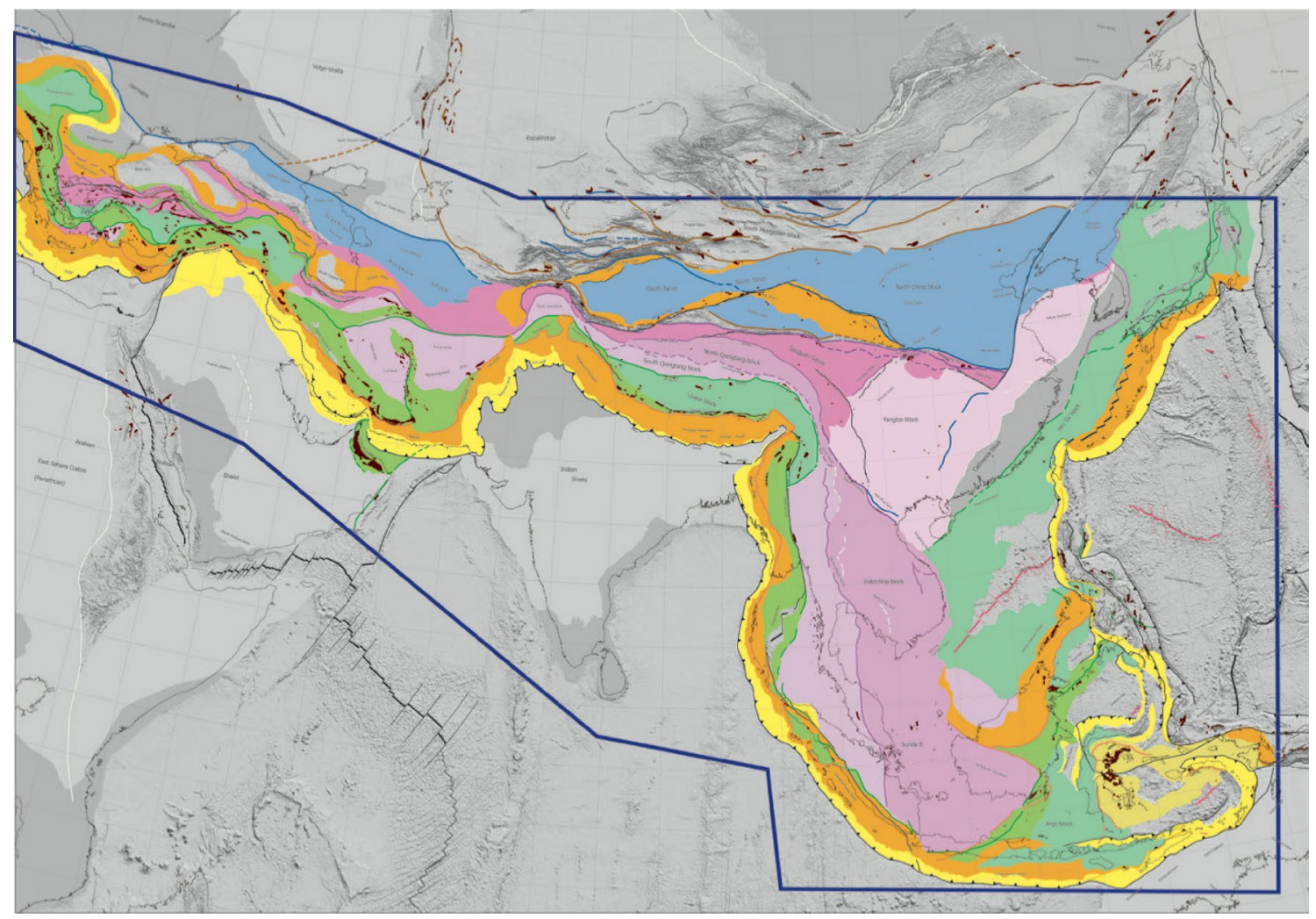

Fig. 1 Spatial Extent of Asian Tethysides, the outcomes of the development of the Asian Tethyan Realm. As to the mechanism and processes of how they became such a configuration, we remain in a state

IGCP-589 held its Second and Third International Symposia with field excursions in Philippines (November 2013) and Iran (October 2014), respectively. Some papers presented at these symposia together with those contributed by colleagues who did not attend the meetings constituted the basis of this special issue of the International Journal of Earth Sciences.

Finally a total of 14 papers are included in this issue, dealing with geological problems in certain parts of the Tethysides from different aspects. These papers provide multi-disciplinary data from key areas and offer constraints on regional developments of the Asian Tethyan Realm. They touched on, from west to east, Turkey, Iran, the Qinghai-Tibet Plateau, the Qinling Orogen, western Yunnan, mainland Southeast Asia, and the Japanese islands.

Turkey is a territory which embodies a number of continental blocks and sutures, resulting from phased development of Tethys in this region over several periods. Köksal et al. examined the ophiolitic rocks in the Ekecikdag (Aksaray/Central Turkey) region, trying to get information to elucidate the properties of the so-called I'zmirAnkara-Erzincan branch of Neotethys. Their geochemical and isotopic data, mostly of the Ekecikdağ plagiogranite, allowed them to suggest that the Ekecikdağ plagiogranite of finding out further clues and indications. Extracted and slightly modified from Pubellier (2008) (Structural Map of Eastern Eurasia, CGMW, Paris)

was generated in a short time-interval from a depleted mantle source in a SSZ/fore-arc basin setting, and was further modified by a subduction component during intra-oceanic subduction.

Iran is often simply known as composed of a Paleotethys suture in north (the Alborz), a Neotethys suture in south (the Zagros) and several continental blocks in between (e.g. the Yazd, Lut, and Tabas blocks). However, reasonable explanations for causes and evolution processes leading to such a configuration are waiting urgently for further supporting materials. Fassihi et al. described Fusulinoids from the Bashkirian-Moscovian transition beds in a new section of the Shahreza area in the Sanandaj-Sirjan Zone, which is a belt parallel on the northeast side of the Zagros Orogen. They also correlated the fauna with coeval ones in other places in Iran, Central Taurides, the Urals, and the Russian platform. Zhang et al. used new in situ detrital zircon $\mathrm{U}-\mathrm{Pb}$ and $\mathrm{Hf}$ isotopic analyses from a Cenozoic sedimentary sequence in SW Iran of the Zagros Orogen to unravel the amalgamation history of Neo-Tethys. Unlike the previously published model, which suggests that the sequence studied lay on the Arabian passive margin and that initial collision occurred prior to $18 \mathrm{Ma}$, the model they favored 
suggests that Paleogene to Upper Miocene sediments were sourced from the northern Neo-Tethyan accretionary complex or Eurasia, and carry no input from Arabia, whereas the Lower Pliocene sample shows a mixed provenance from both Arabia and Eurasia, suggesting that the collision occurred between $\sim 11.2$ and $5 \mathrm{Ma}$.

The Qinghai-Tibet Plateau is a major component of the Asian Tethysides. Its evolution has been drawing attention from different aspects. Zhai et al. presented $\mathrm{U}-\mathrm{Pb}$ dating and geochemical results of metamorphic zircons from the eclogite in the boundary zone between the North and South Qiangtang (sub)terranes. This zone embodies very probably the traces of Paleo-Tethys. The zircon grains contain numerous eclogite-facies mineral inclusions, including omphacite, phengite, garnet and rutile, but also show euhedral crystal habit, high $\mathrm{Th} / \mathrm{U}$ ratios and enriched heavy rare earth elements pattern. Systematic analyses enabled them to interpret the zircon $\mathrm{U}-\mathrm{Pb}(232-237 \mathrm{Ma})$ and mineral $\mathrm{Lu}-\mathrm{Hf}$ isochron ages as the time of the peak eclogite-facies metamorphism, and the rutile U-Pb (ca. $217 \mathrm{Ma}$ ) and phengite $\mathrm{Ar}-\mathrm{Ar}$ ages as the time of exhumation to the middle crust.

Late Triassic silisicalstic successions are extensively exposed parallel to the south of the Yarlung Zangbo Suture Zone. Large thickness and flyschoid appearance are two significant features of them. Their deposition is considered to have been closely related to the development of the oceanic basin now represented by the Yarlung Zangbo Suture Zone. Zhang et al. carried out systematic sedimentological studies of these sediments, the Langjiexue Group, in the Shannan region. Unlike existing interpretations of these Late Triassic successions, such as deep-sea sediments of the Tethyan Himalaya, or accretionary prism within the mélange belt of the Yarlung Zangbo Suture Zone, they suggested that the Langjiexue Group accumulated in a remnant basin between Lhasa, Greater India, and Australia.

The Bangong-Nujiang suture zone is another recognized suture zone in the Qinghai-Tibet Plateau, whose developing history, however, has not yet been properly understood. Lai et al. presented for the first time the presence of Early Jurassic mélange from NW Nagqu in the southern margin of the Bangong-Nujiang suture zone, and named it Gajia mélange. It shows typically blocks-in-matrix structure, with matrix of black shale and siliceous mudstone, and blocks of several centimeter- to several meter-sized sandstone, silicalite, limestone and basalt. It was divided into three lithological groups and has been examined with routine petrographic methods and $\mathrm{U}-\mathrm{Pb}$ dating and isotopic analysis of detrital zircons. Their results tend to indicate that the sandstone blocks in the Gajia mélange were from the Lhasa terrane, and the mélange was resulted from the southward subduction of the Bangong-Nujiang oceanic lithosphere during the Early Jurassic.
The direction of subduction of the Bangong-Nujiang oceanic lithosphere has been reported either southward or northward or both. Li et al. studied the newly discovered Early Cretaceous (ca. $100 \mathrm{Ma}$ ) Moku pluton (granites with dioritic enclaves) in the southern Qiangtang (sub)terrane. Their zircon U-Pb dating, whole rock geochemistry, and $\mathrm{Sr}-\mathrm{Nd}-\mathrm{Pb}$ and zircon $\mathrm{Hf}$ isotopic data are interpreted to support the idea that the ca. 100 Ma magmatic rocks were derived from anatexis of the Qiangtang lower crust that mixed with upwelling asthenosphere materials in response to the slab break-off of the northward subduction of the Bangong-Nujiang oceanic lithosphere.

The Qinling-Dabie Orogen is a composite orogen representing the multistage collision and suturing of the North China and South China blocks (very probably also a few marginal fragments in between) from the Late Paleozoic to Triassic. The closure of this branch of Paleo-Tethys is considered to be more or less a scissor action. Ji et al. tackled, however, the extension in the Dabie region a time after the orogen was formed. They focused on the Dabieshan metamorphic core complex and succeeded in getting a number of implications for the extensional collapse of the Triassic HP-UHP orogenic belt in east-central China. They proposed that the occurrence of the Dabieshan metamorphic core complex is a result of the Cretaceous continental-scale NW-SE extension in eastern Asia.

The Baoshan Block in western Yunnan, China is a Gondwana-derived block. Early Permian diamictites and cold/ cool-water faunas indicate that the block was located in the northern margin of Gondwana until at least the Early Permian. Middle Permian saw an apparent areolation of climate as indicated by carbonate successions and occurrence of certain number of Cathaysian fossil elements. Huang et al. described for the first time in detail Wordian-early Wuchiapingian ooids found in Permian carbonates of the Baoshan Block. Their findings plus published data allowed them to line out a diachronous debut of Permian ooids among the Gondwana-derived blocks: mostly Sakmarian in Central Taurides of Turkey, Central Iran, Central Pamir and Karakorum, and Wordian-Capitanian in the South Qiangtang Block, Baoshan Block, and Peninsular Thailand.

The Ailaoshan suture in Yunnan, China joins the South China and Indochina blocks. Liu et al. carried out zircon $\mathrm{U}-\mathrm{Pb}$ dating and geochemical investigations of amphibolite (metamorphosed Late Triassic gabbroic intrusion) and granitic gneisses (metamorphosed Late Triassic granitic plutons) in two localities. Their results tend to show that the suture zone entered a post-collisional setting in the Late Triassic, and accompanied slab break-off triggered the OIB-type asthenospheric mantle upwelling and provided the heat source for the Late Triassic magmatic flare-up.

Mainland Southeast Asia is a composite of continental blocks of varied histories sutured together as results of the 
development of Tethys. Three papers deal with, respectively, specific problems in Thailand, Myanmar and Laos. Qian et al. presented geochronological, geochemical results and zircon $\mathrm{Hf}$ and $\mathrm{O}$ isotopic data of their newly identified Triassic I-type rhyolite in the Chiang Khong area of Northeast Thailand. Zircon $\mathrm{U}-\mathrm{Pb}$ dating provides an age of $230.7 \pm 1.1 \mathrm{Ma}$ for the Chiang Khong rhyolites. Geochemical data were interpreted as suggesting that the Chiang Khong rhyolites were formed by partial melting of juvenile mafic lower crust in a post-collisional setting, and deep crustal anatexis was probably induced by upwelling asthenospheric mantle shortly after slab detachment subsequent to the closure of Paleo-Tethys.

Zhang et al. presented their mapping results of the Mindat and Magwe sections in the middle Indo-Burma Range (IBR) of Myanmar. They found a $\sim 18 \mathrm{~km}$ antiformal isocline in a mélange in which green schist facies rocks are in the core and the metamorphic grade decreases eastwards and westwards to sericite schist and silty slate, and finally to unmetamorphosed sediments, and these metamorphic rocks are structurally repeated in small-scale imbricated thrust stacks. Their field investigation and laboratory results tend to indicate that the IBR metamorphic rocks were exhumed by wedge extrusion in a subduction-generated accretionary complex.

Wang et al. carried out petrological, whole-rock geochemical, and $\mathrm{U}-\mathrm{Pb}$ geochronological work on Cretaceous red beds of a section in the Muang Xai Basin, northern Laos, which is associated with the Simao (China), Vientiane (Laos) and Khorat (Thailand) Basins. Their investigation results suggest that the sedimentary sources of the studied section include felsic rocks from an active continental margin or continental arc and recycled passive continental margin sediments. These sources were shared with coeval sediments in the Simao and Khorat Basins.

Japanese islands have a very complicated formation history. It is gradually acknowledged that a significant contribution has been accomplished by the accretion of trench-fill sediments, oceanic plate cover, and terranes with strike-slip tectonic movement. It is, especially so for southwestern Japan. Tsukada et al. studied the geochemistry of the Lower Paleozoic basalt formation (Iwatsubodani Formation) in the Hida Gaien belt, Japan, to acquire useful information about its tectonic setting. Their efforts let them to conclude that the Iwatsubodani Formation probably formed in a primitive SSZ system in the Early Paleozoic.
We are very grateful to colleagues who have actively participated in the IGCP-589 project and contributed enthusiastically to this special issue. We acknowledge the support of IUGS and UNESCO for the successful operation of the project. We are also indebted to the Editor-in-Chief of the Journal, Wolf-Christian Dullo, for his support and collaboration in the preparation of this special issue. More than 30 reviewers provided constructive and critical comments and suggestions that significantly improved the quality of the papers included this issue, for which we appreciate very much.

\section{References}

Gregory JW (1915) Interpretation of Suess's classification of Eurasian mountains. Geogr J 45(6):497-513

Huang J, Chen B (1987) The evolution of the Tethys in China and adjacent regions. Geological Publishing House, Beijing, pp $1-109$

Jin X, Wang Y, Xie G (2003) Devonian to Triassic successions in the Changning-Menglian Belt, western Yunnan, China. Acta Geologica Sinica 77(4):440-456

Jin X, Huang H, Shi Y, Zhan L (2015) Origin of Permian exotic limestone blocks in the Yarlung Zangbo Suture Zone, Southern Tibet, China: with biostratigraphic, sedimentary and regional geological constraints. J Asian Earth Sci 104:22-38

Metcalfe I (2013) Gondwana dispersion and Asian accretion: tectonic and palaeogeographic evolution of eastern Tethys. J Asian Earth Sci $66: 1-33$

Pubellier M (2008) Structural Map of Eastern Eurasia (1:12 500 000). Commission for the Geological Map of the World, Paris

Ren J, Niu B, Wan J, Jin X, Xie L (2013) International Geological Map of Asia (1:5 000 000). Geological Publishing House, Beijing

Şengör AMC, Atayman S (2009) The Permian extinction and the Tethys: an exercise in global geology. Geol Soc Am Spec Paper 448:1-96

Şengör AMC, Natal'in BA (1996) Palaeotectonics of Asia: Fragments of a synthesis, in Yin A, and Harrison M, eds., The Tectonic Evolution of Asia, Cambridge University Press 486-640

Şengör AMC., Altıner D, Cin A, Ustaömer T., Hsü KJ, 1988, Origin and assembly of the Tethyside orogenic collage at the expense of Gondwana-Land, in Audley-Charles MG, and Hallam A, eds., Gondwana and Tethys, Geological Society, London, Special Publication 37:119-181

Suess E (1893) Are great ocean depths permanent? Nat Sci 2(13):180-187

Wopfner H, Jin X (2009) Pangea Megasequences of Tethyan Gondwana-margin reflect global changes of climate and tectonism in Late Palaeozoic and Early Triassic times-a review. Palaeoworld 18:169-192 